\title{
Aurora Vergara-Figueroa Afrodescendant Resistance to Deracination in Colombia. Massacre at Buenavista-Bojayá-Chocó
}

\author{
Cham, Switzerland: Palgrave Macmillan \\ Cham, Switzerland, 2018, 123 pp. \\ ISBN 978-3-319-59760-7
}

Fernando Esquivel-Suárez, Ph.D./ Spelman College

Aurora Vergara-Figueroa's book Afrodescendant Resistance to Deracination in Colombia is a leap forward in analyzing the Colombian conflict from what writer Alice Walker would call a womanist perspective. This Black feminist frame allows Vergara-Figueroa to connect a particular event - the massacre of Bellavista, Bojayá in 2002 - to structural violence against Afro-Colombian communities and to capitalism's global color line. Using this approach and extensive oral history, this research produces two major claims: first, it shows how the consequences of this massacre cannot be adequately described or addressed by commonly used categories including "forced migration" or "displacement." Vergara-Figueroa proposes instead using the concept "deracination" to accurately conceptualize, historicize, prevent, and mitigate the effects of structural land-grabbing violence against Afro-Colombian communities. Second, Vergara-Figueroa's book analyzes religious songs by Afro-Colombian women-known as alabaos - as tools for communal healing as well as for political denunciation and resistance. With these goals in mind, Vergara-Figueroa divides the book in five chapters. The first one is a theoretical chapter where the author introduces the concept of deracination. Chapter 2 connects Bellavista with the history of deracination the African diaspora. In chapter 3 , Vergara-Figueroa reconstructs the oral history of the massacre narrated by women who survived it. Chapter 4 is a study of alabaos as an Afro diasporic mechanism of resistance. The book finishes in chapter 5 with a theoretical review of Black feminist theories and their importance in building resistance and alternative narratives.

In chapter 1, Vergara-Figueroa assembles a theoretical framework to answer her guiding question for this book about the creation of spaces for land dispossession. Following the theoretical traditions of Agustin Lao-Montes and Santiago Arboleda, the author defines deracination as "uprooting from the ground [...] breaking the communal relations" (17). The concept of deracination implies a longue durée historical analysis avoiding the study of massacres in isolation. Opening the scope of analysis beyond the current Colombian civil war, this book shows how during the last four centuries
Bellavista has experienced cycles of violence and migrations in every period of major economic and political development. The author reveals the cyclical nature of this phenomenon by applying the analytical tool D-T-D2 (Diaspora-Territorialization-Deracination/Diaspora). This methodology incorporates the history of initial territorial settlement, followed by dispersion and dislocation, the politicization of diaspora as a project of affinity, and resettlement in new territories where the experiences of deracination will be repeated.

In chapter 2, Vergara-Figueroa presents the case of Bellavista as an instance of deracination against Afrodescendants: this process began with their abduction from Africa; the commercialization of the Black body in the Transatlantic Trade and the horror of enslavement; territorial settlement in the Colombian Pacific after manumission; and the reiteration of these cycles of diaspora and resettlement in the nineteenth, twentieth, and twenty-first centuries. In Colombia, the majority of massacres that produce high percentages of so-called "displaced" people occurre in regions such as the Department of Chocó, where Buenavista is located, where $82.7 \%$ of the population is of African descent. These regions and their communities carry the racist stigma of Blackness understood as poverty and marginality. Such ideas are foundational to legitimize bloody land-grabbing practices in detriment of Afrodescendant communities represented as occupants of marginal territories in need of civilization. Through deracination, Vergara-Figueroa also connects this massacre with the global expansion of capitalism by reminding us that millions of people are deracinated by development projects every year. However, the book does not explore concrete examples that solidify the connection sketched between this particular case and the role of deracination in globalized economies.

Using five family interviews, an archive of translated songs, and her journals from several visits to Bellavista, in chapter 3 Vergara-Figueroa weaves a collective narrative of the massacre as an alternative to the official account of the event in which the government exclusively blamed the guerrilla forces for killing approximately 119 civilians, 
and the community's subsequent "displacement." Inserting Spanglish to maintain the voices of the interviewed women through multiple layers of translation and conceptualization, Vergara-Figueroa follows the process of dehumanization that allows this recurrent form of violence over Afro-Colombian communities. The chapter also explains how the categorization of these communities as "displaced" produces their revictimization. The narrative formed from the collective voices of the women in the community is framed, almost buried, under very long theoretical and methodological chapters. In my opinion, this rigid disciplinary organization hinders the already hard task of having these voices speak for themselves, almost as if only the theoretical explanation could legitimizes their existence, undermining the purpose of uplifting them.

Following the premise that observing this massacre in isolation also obliterates social mobilization, in chapter 4 Vergara-Figueroa studies Afro-Colombian women's religious songs known as alabaos, as an instance of ethno-territorial resistance. After reading more than 250 lyrics collectively written, Vergara-Figueroa noticed that the song books in Bellavista were different from those composed by other Afro-Colombian parishes. Going beyond religious motives, women in Bellavista transformed them into hymns of autonomy and self-determination as well as spaces for recounting their version of the event, and for denouncing those responsible for the violence against their community. In this chapter, the author also draws connections between African-American spirituals and Bellavista's alabaos. However, the chapter ends abruptly before offering historical context for the songs or a structural study comparing them to other diasporic productions. This chapter would have also benefited from a section on the circulation and reception of the songs. In chapter 5, Vergara-Figueroa builds up on the definition of Afro-Latin American feminism by authors including Leila González and Sônia Beatriz dos Santos. In these final reflections Vergara-Figueroa highlights the importance for AfroLatinx women to appropriate Diasporic womanism and to analyze Black women's central role in reorganizing social, economic and political structures after collective trauma.

Vergara-Figueroa's book successfully argues against the use of limiting concepts such as "displacement" to explain the massacre in Bellavista, Bojayá. Deracination, instead, incorporates into the analysis cycles of ethical-historical land-grabbing violence, allowing the design of policy to prevent it and to mitigate its effects. 